\title{
How to Improve Performance of Lecturer: A Case Study of School of Health Sciences in Capital City of Indonesia
}

\author{
Hendy Tannady ${ }^{1}$, Alex Zami ${ }^{2}$ \\ Management Department, Universitas Pembangunan Jaya, Banten, Indonesia ${ }^{1}$ \\ Management Department, Sekolah Tinggi Ilmu Ekonomi YAI, Jakarta, Indonesia ${ }^{2}$
}

\begin{abstract}
This research is aimed to analyze and determine the effect of self efficacy, organizational culture and leadership on work motivation and its implications on performance of permanent lecturers of School of Health Sciences (SHS) in province of Jakarta, the capital city of Indonesia. The analysis model uses Structural Equation Model (SEM). Partially self-efficacy provides most dominant contribution in influencing work motivation. Simultaneously, self efficacy, organizational culture, leadership and work motivation have a positive and significant effect on performance of permanent lecturers with a contribution of $\mathrm{R}^{2}$ of $79 \%$, partially leadership provides most dominant contribution in influencing performance. The respondents were those who working as permanent lecturers in College of Health Sciences, while the survey was conducted to 325 lecturers. The respondents must be have at least master degree as their educational background. Another finding from the results of this study is that work motivation acts as a partial mediating of self-efficacy and organizational culture toward performance of permanent lecturers. The advice given to increase motivation is to focus on efforts to increase self efficacy of permanent lecturers, especially in dimension of magnitude. While to improve performance is by focusing on efforts to improve leadership, especially in dimension of academic leadership.
\end{abstract}

Keywords: Performance, Permanent Lecturers, School of Health Sciences

\section{Introduction}

A strong nation is very determined by the quality of human resources. Various aspects affect the quality of human resources in a country, such as education, fulfillment of basic needs (food, clothing and housing) and health. Especially regarding health, through nine nawacita programs launched by the government, the government is determined to develop Indonesia from the periphery by strengthening villages, the government is also determined to improve human quality and improve productivity and competitiveness of the people in international markets. Surely this program will be difficult to materialize without health insurance for the Indonesian people. To support this program, the quantity and quality of human resources who responsible in the health sector is very necessary in helping the government carry out various health assistance functions, such as treatment, counseling, and 
so on. Especially the quality of human resources in the health sector is certainly influenced by the quality of graduates from institutions which focusing on health or medical sciences, and quality of graduates is strongly influenced by the performance of permanent lecturers at each of these institutions. The performance of permanent lecturers also contributes to the performance of institutions, one of the institutions that produces human resources that have expertise in the field of health is the School of Health Sciences.

According to the Regulation of Ministerial of Utilization of State Apparatus and Bureaucratic Reform No. 17 Year of 2013 concerning the Lecturer Functional Position and Credit Score, the definition of a lecturer is a professional educator and scientist with the main task of transforming, developing, and disseminating science, technology and art through education, research, and community service. Based on this definition, the lecturer is the main instrument in higher education and an important figure behind the successful performance of higher education institutions. Based on Regulation of Ministerial of Research, Technology and Higher Education No. 44 Year of 2015 concerning National Standards of Higher Education, the parameters of the performance of lecturers are measured from the implementation of tri dharma, namely education and teaching, research and community service. Every lecturer in Indonesia has a minimum performance standard of 12 creditsin each semester, 12 credits consisting of 9 credits in education and research and 3 credits in the field of community service and supporting tasks. A lecturer is obliged to conduct research and community service at least once a year. Lecturers who have a academic position of associate professor and professor are required to conduct scientific publications at the international level once in a year and must be able to publish one textbook within two years.

Human resources are an important factor for organizations (Aslam et al., 2015; Tannady et al., 2017). Higher performance of human resources will have an impact on the high quality of work in completing each task given (Rizal et al., 2014). Many variables related to industrial psychology have been proven to influence organizational performance, one of which is work motivation (Ghaffari et al., 2017; Qatmeemalmarhoon et al., 2017; Robescu and Iancu, 2016; Mensah and Tawiah, 2016). Nidhi et al. (2012) show that success of organization depends on how effective and efficient employee performance and motivation are, adding that employees are "basic building blocks" in an organization. One of the things that can affect performance is motivation (Salleh et al., 2011). The same thing is also reinforced by the results of research was conducted by Omollo (2012) which examined the effect of motivation on performance at a commercial bank in Kenya, where the conclusion of the study was that motivation had an influence on the performance of an employee in the bank. Through his research that took the object of research in the soft drink industry in Pakistan, Zameer et al. (2014) concluded that there is a relationship between motivation and employee performance, where motivation can affect performance. There are various factors that cause the motivation of an employee to contribute to the company. Various kinds of external factors that influence motivation include self efficacy, organizational culture and leadership.

Research conducted by Cerino (2014) at a university in the United States using a sample of 101 bachelor degree students shows that self efficacy influences the development of student motivation, especially in the academic field. Organizational culture is a factor that also influences the motivation of human resources, based on research conducted by Hani et al. (2016) shows that there is a very close relationship between organizational culture and motivation. Research conducted by Rawung (2013) shows that there is a significant influence of leadership on employee motivation, especially in institution of higher education. The same thing was also found in research conducted by Wagimo and Ancok (2005) and Naile and Selesho (2014). Data obtained from forlap.ristekdikti.go.id, from 499 permanent lecturers of 
SHS in Jakarta, most of the permanent lecturers have the educational background as master degree $(73.14 \%)$ and doctoral degree $(4.02 \%)$, while $3 \%$ of permanent lecturers still have Diploma certificate and $19.84 \%$ of permanent lecturers still have a bachelor's degree as their educational background. This data shows that there is a problem in terms of the level of education of the permanent lecturers of SHS, where $22.84 \%$ still do not have a minimum master degree as required by Law No. 14 year 2005 Article 46 concerning teachers and lecturers.

In terms of academic level, $71.54 \%$ still do not have academic degrees, $21.64 \%$ have an instructor rank, $6.61 \%$ have senior lecturer rank and $0.2 \%$ have an associate professor rank. This data shows that there are problems in terms academic levels of lecturer, more than $50 \%$ of permanent lecturers of SHS still do not have lecturer academic positions as required in Law No. 14 year 2005 Article 48 concerning teachers and lecturers, wherein a lecturer has at least an academic position of instructor. Based on the released reports contained list of lecturer who receive grants in research and community service in 2017 , only $2.8 \%$ of lecturers obtained research funding and $0 \%$ obtained community service funding, while from the data of publication reported, the number of publications was only $45,89 \%$ of the total number of lecturers, this is an indication that there is a problem with the performance of SHS permanent lecturers in Jakarta.

Survey on 100 students and 30 permanent lecturers to identify motivation and performance of lecturers. Data from the survey shows that on average $45.8 \%$ of respondents are still unsatisfied and $16.4 \%$ of respondents are still very dissatisfied with the motivation of SHS permanent lecturers in Jakarta in terms of teaching. Regarding several indicators that reflect motivation related to research and community service, from the survey obtained data that an average of $43.28 \%$ of respondents were unmotivated and $9.14 \%$ of respondents were very unmotivated to perform various forms of activities categorized as research activities, while In terms of community service, survey data obtained an average of $49.75 \%$ of respondents were unmotivated and $11.25 \%$ of respondents were very unmotivated to perform various forms of activities categorized as community service activities. Surveys related to the performance of teaching conducted on students as respondents showed that $13.8 \%$ of respondents felt very dissatisfied and $38.7 \%$ of respondents felt dissatisfied with the performance of permanent lecturers in terms of teaching. Another indicator of the performance of SHS permanent lecturers is number of accredited SHS, data from forlap.dikti.go.id shows that Jakarta is in the bottom thre of provinces with the number accredited SHS, only 1 of 16 SHS has been accredited with $\mathrm{C}$ status of accreditation.

Based on several studies that have been carried out on variables that have a role in influencing performance, self efficacy, organizational culture, and leadership are positioned as influential or exogenous variables $(\mathrm{X})$, while work motivation is positioned as a moderating variable (Y1) and performance is positioned as an endogenous variable (Y2). Objective of this research is to analyze and examine the effect of each exogenous variable both partially and simultaneously on endogenous variables.

\section{Literature Review}

\subsection{Self Efficacy}

Self-efficacy theory also known as social cognitive theory, or social learning theory, refers to an individual's belief that he is able to carry out the given tasks (Rosen et al., 2006; 
Bandura, 2005). According to Schermerhorn (2010) self-efficacy is a self-confidence that refers to one's belief that he is able to carry out a particular task and self-confidence is very necessary for someone in facing certain tasks that are full of challenges and require specific actions. According to Ivancevich et al. (2011) self efficacy relates to self-confidence in competence and abilities. People with low self-efficacy tend to reduce their efforts, while people with high self-efficacy will try harder to conquer the challenge (Ferris et al., 2005; Vigoda, 2002 ; Stajkovic \& Luthans, 1998). According to Bandura (2005) self efficacy in individuals can be analyzed based on three dimensions, namely magnitude (level of difficulty), generality (area of behavior) and strength (strength of belief).

\subsection{Organizational Culture}

Davis and Newstorm (2005) state that organizational culture is a pattern of organizational beliefs and values that are understood, imbued and practiced by the organization so that the pattern gives its own meaning and becomes the basis of the rules of behavior in the organization. Organizational culture is a set of beliefs, assumptions, norms and values and has been accepted or shared with all members in an organization (Nidhi et al., 2012). Robbins and Judge (2015) state that organizational culture is a shared meaning system formed by its people which at the same time becomes a differentiator from other organizations. There are seven characteristics given by Robbins (2013) in defining organizational culture, namely innovation and risk-taking courage, attention to detail, results-oriented, human-oriented, team-oriented, aggressive and stability. The function of organizational culture according to Robbins and Judge (2015) is as a differentiator between one organization and another, bringing a sense of identity to members of the organization, facilitating the emergence of commitment to something wider than individual interests, and increasing the stability of the social system.

\subsection{Leadership}

Siddique et al. (2011) defines leaders as someone who inspires and able to bring and direct followers to realize goals. According to Ivancevich et al. (2011) leadership is the process of influencing others to support the achievement of relevant organizational goals. Kotter (2005) in Northouse (2007) presents a model of management and leadership functions, where management has a function in generating order and consistency, while leadership has the function of generating change and movement. According to Bass (2010) and Kirkpatrick and Locke (2001) some personal character in a leader, such as honesty and integrity, enthusiasm, lead desire, independence, persistence in achieving goals and challenges, tenacity, intelligence, cognitive abilities, assertiveness, cooperation, diplomacy and educational background. Specifically in academic institution, Siddique et al. (2011) discussed three dimensions of leadership, namely institution leader, academic leader and administration leader.

\subsection{Work Motivation}

According to Maslow (1943), human motivation is divided into five needs, namely physiological needs, security needs, social needs, appreciation needs, and self-actualization needs. Maslow's theory assumes that people tend to strive the fulfillment of basic needs (physiological) before directing their behavior to the higher needs. According to McClelland (1985), human motivation is divided into three needs, namely achievement needs, affiliate 
needs, and power needs. According to McClelland, someone will have a better motivation if he has a desire to achieve better than others. Motivation according to Herzberg (1959) consists of two factors, namely motivator factor and hygiene factor. Motivator factors or motivational factors are factors that cause job satisfaction, such as institutional concern toward performance achievement, objective assessment of work performance, recognition and appreciation of performance and service, efforts to improve work quality, efforts to always work effectively and efficiently, and satisfaction in solving difficult problems. While hygiene factors are factors that cause job dissatisfaction, such as compensation factors, good relationships in the workplace, supervision of superiors, pride in work status, personal life factors, and job security factors (Tannady, Erlyana \& Nurprihatin, 2019). Grund and Sliwka (2001) suggest that motivation can be in the form of financial or non-financial, which can affect job satisfaction.

\subsection{Performance}

Performance is one indicator of productivity and profitability, performance is a priority for the organization in achieving organizational goals. Performance is seen as a measure of the success of an employee at work (Hee \& Kamaludin, 2016; Tannady et al., 2019). Job performance indicates things that need to be done in the job description, this also means it can be assessed and become a benchmark for the organization in giving awards based on employee contributions to the creation of good organizational performance (Gunawan et al., 2020). In an organizational context, a series of procedures make work behavior predictable and some basic work can be completed to achieve organizational goals (Janssen \& Van Yperen, 2004). Job performance is essential in achieving organizational objectives that are carried out consistently and effectively (Mehmet, 2013; Tannady et al., 2020). Good performance will reduce labor costs, increase organizational profits and create customer loyalty (Earls, 2004).

\section{Theoretical Framework}

Based on a series of theories and previous research, a theoretical framework for research was built. Figure 1 shows the theoretical framework of research that was built in the study.

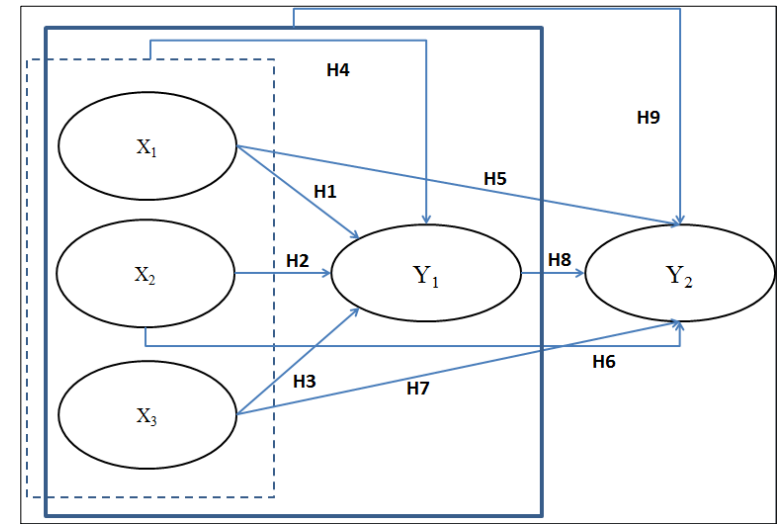

Fig. 1. Theoretical Framework 
Note :

$\mathrm{X}_{1}=$ Self Efficacy

$\mathrm{X}_{2}=$ Organizational culture

$\mathrm{X}_{3}=$ Leadership

$\mathrm{Y}_{1}=$ Work motivation

$\mathrm{Y}_{2}=$ Performance

\section{Research Hypothesis}

Based on the above framework, nine research hypotheses can be made, as follows:

H1: Self efficacy has a positive and significant effect on the work motivation of permanent lecturers

$\mathrm{H} 2$ : Organizational culture has a positive and significant effect on the work motivation of permanent lecturers

H3: Leadership has a positive and significant effect on the work motivation of permanent lecturers

H4: Self efficacy, organizational culture and leadership simultaneously have a positive and significant effect on the work motivation of permanent lecturers

H5: Self efficacy has a positive and significant effect on the performance of permanent lecturers

H6: Organizational culture has a positive and significant effect on the performance of permanent lecturers

H7: Leadership has a positive and significant effect on the performance of permanent lecturers

H8: Work motivation has a positive and significant effect on the performance of permanent lecturers

H9: Self efficacy, organizational culture, leadership and work motivaton simultaneously have a positive and significant effect on the performance of permanent lecturers

\section{Methodology}

The type of study is descriptive and verificative. Operationally, the measurement of variable of self efficacy using three dimensions, namely magnitude, generality, strength. Measurement of variable of organizational culture using five dimensions, namely innovation and risk taking, attention in detail, orientation to the result, orientation to human resources, and performance culture. The measurement of variable of leadership using three dimensions, namely academic leader, institutional leader, and administration leader. Measurement of variable of work motivation using two dimensions, namely motivator factors and hygiene factors. The measurement of variable of performance using three dimensions, namely education and teaching, research, and community service. Total number of indicators is 65 statement indicators.

Types of data are divided into primary and secondary data. Secondary data is information relating to the environmental conditions of universities in Jakarta, such as the number of institutions based on their type, number of institutions in each region in Indonesia, number of accredited institutions, number of lecturers based on their educational background, number of lecturers based on academic rank, and number of students. The primary data is collected directly from the research object by determining the sample size. 
The sample size is determined using purposive sampling judgment technique, the population is permanent lecturers of SHS in Jakarta. Determination of the number of samples according to Hair et al. (2010) it is recommended to survey 5 to 10 respondents for each indicator. If 5 people are estimated for each indicator, the expected number of samples is 325 people. The population is 499 people, considering the educational background criteria, so that the population in this study is 385 people (the population consisted of lecturers who have at least master degree as educational background). The distribution of sample collection was 1.82\% (North Jakarta), 3.89\% (West Jakarta), 9.87\% (Central Jakarta), 49.87\% (East Jakarta), and $34.54 \%$ (South Jakarta). According to Hair et al. (2010) the indicator is declared valid if the value of loading factor is $>0.50$, while the indicator is declared reliable if the value of variance extracted $(\mathrm{VE})$ and construct $(\mathrm{CR})>0.50$. Hypothesis testing uses structural equation modeling (SEM) and data analysis using the LISREL.

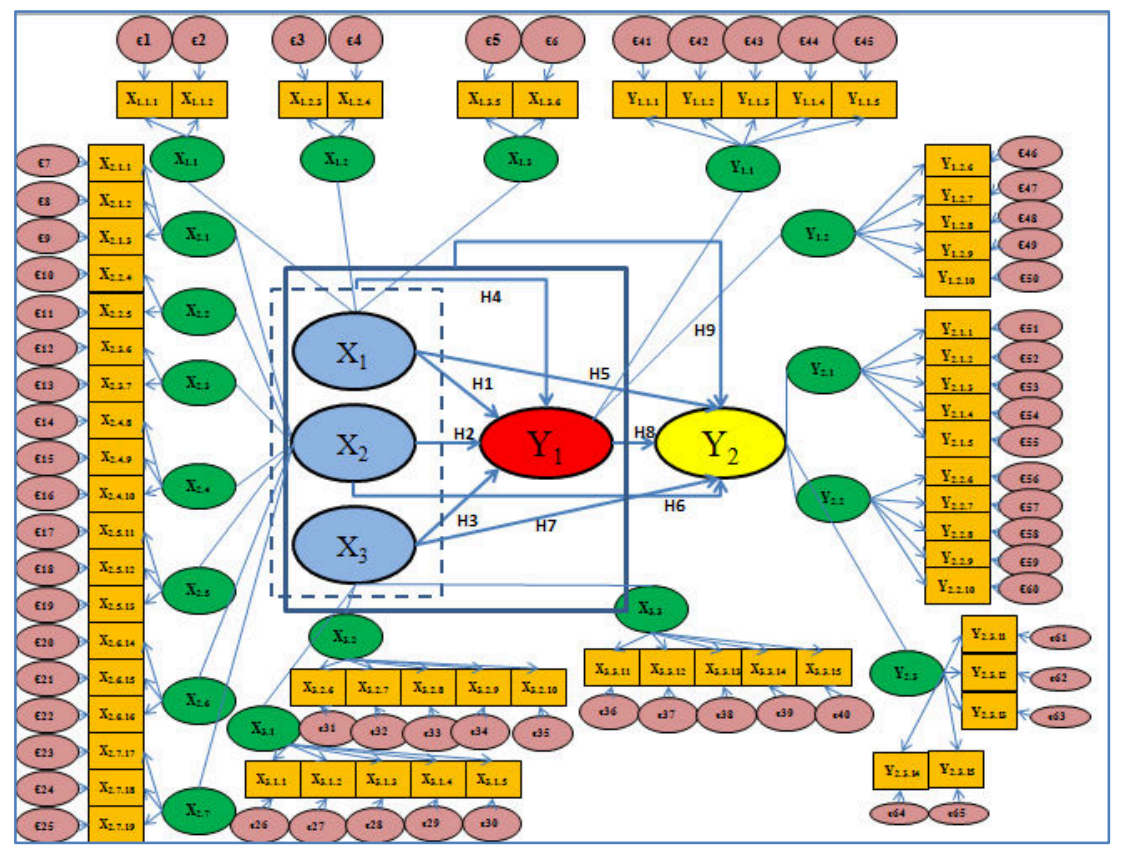

Fig. 2. Research Path Diagram

\section{Result and Discussion}

Questionnaires were distributed to 325 respondents who met four criteria, namely the respondent is a permanent lecturer at SHS in Jakarta, the respondent had taught for at least one academic year at the university where he was homebase, the respondent had interacted and received direction from the leader (at least secretary of study program) and respondents have a minimum educational background of master degree. Furthermore, descriptive analysis of respondents' profiles is based on several characteristics. By gender, $42.15 \%$ are men and $57.85 \%$ are women. Based on age, age less than 25 years $(3.08 \%), 25-35$ years $(28.61 \%),>35$ - 45 years $(52 \%),>45$ years $(16.31 \%)$. The educational background was categorized into two, master degree $(96.92 \%)$ and doctoral degree (3.08\%). Lecturer academic position is 
categorized into five, teaching staff (61.85\%), instructor (32.92\%), senior lecturer (5.23\%), associate professor and professor $(0.00 \%)$. Working period is categorized into four, 1 - 2 years $(20 \%),>2-5$ years $(36.31 \%),>5-10$ years $(37.54 \%)$, and $>10$ years $(6.15 \%)$.

\begin{tabular}{lccllll}
\multicolumn{7}{c}{ Table 1. Validity and Reliability Test } \\
\hline Variable & Dimension & SLF & Validity & CR & VE & Reliability \\
\hline Self Efficacy & SM & 0.96 & Valid & 0,935 & 0,637 & Reliable \\
& SG & 0.89 & Valid & & & \\
Organizational Culture & SS & 0.92 & Valid & & & \\
& BI & 0.98 & Valid & 0,931 & 0,850 & Reliable \\
& BP & 0.95 & Valid & & & \\
& BOH & 0.95 & Valid & & & \\
& BOM & 0.94 & Valid & & & \\
& BOT & 0.86 & Valid & & & \\
Leadership & BOA & 0.89 & Valid & & & \\
& BOS & 0.92 & Valid & & & \\
Work Motivation & KAC & 0.77 & Valid & 0,969 & 0,740 & Reliable \\
& KI & 0.72 & Valid & & & \\
Performance & KAD & 0.75 & Valid & & & \\
& MM & 0.99 & Valid & 0,895 & 0,642 & Reliable \\
& MH & 0.97 & Valid & & & \\
& KPP & 0.86 & Valid & 0,957 & 0,737 & Reliable \\
& KPN & 0.97 & Valid & & & \\
\hline & KKM & 0.90 & Valid & & & \\
\hline
\end{tabular}

Table 1 shows all statements in the questionnaire are valid because they have SLF values > 0.50 and are reliable because all variables have $\mathrm{CR}$ and VE values $>0.50$. The next step is to do a goodness of fit test.

Table 2. Goodness of Fit Test

\begin{tabular}{llll}
\hline Goodness of Fit Index & Cut-off Value & Result & Evaluation \\
\hline GFI & 0.80 & 0.80 & Marginal fit \\
NNFI & 0.80 & 0.90 & Good fit \\
NFI & 0.80 & 0.90 & Good fit \\
AGFI & 0.80 & 0.80 & Marginal fit \\
RFI & 0.80 & 0.87 & Marginal fit \\
IFI & 0.80 & 0.91 & Good fit \\
CFI & 0.90 & 0.91 & Good fit \\
\hline \multicolumn{4}{r}{}
\end{tabular}

Table 2 shows that the data already has a fit value, from the goodness of fit test using the GFI, NNFI, NFI, AGFI, RFI, IFI and CFI parameters obtained evaluation results that are fit for each parameter. The next step is evaluate the structural path for each exogenous variable to the endogenous variables both partially and simultaneously.

Table 3. Structural Analysis

\begin{tabular}{clccc}
\hline Hypothesis & Structural Path & SLF & t/f-value & Evaluation \\
\hline H1 & Self efficacy $\rightarrow$ work motivation & 0.46 & 9.34 & Significant \\
H2 & Organizational culture $\rightarrow$ work motivation & 0.16 & 2.88 & Significant \\
H3 & Leadership $\rightarrow$ work motivation & 0.26 & 4.46 & Significant \\
\hline
\end{tabular}




\begin{tabular}{clccc}
\hline Hypothesis & Structural Path & SLF & t/f-value & Evaluation \\
\hline H4 & Self efficacy, organizational culture and & 0.43 & 11.26 & Significant \\
& leadership $\rightarrow$ work motivation & & & \\
H5 & Self efficacy $\rightarrow$ performance & 0.25 & 5.38 & Significant \\
H6 & Organizational culture $\rightarrow$ performance & 0.20 & 4.02 & Significant \\
H7 & Leadership $\rightarrow$ performance & 0.50 & 8.99 & Significant \\
H8 & Work motivation $\rightarrow$ performance & 0.27 & 5.56 & Significant \\
H9 & Self efficacy, organizational culture, & 0.79 & 7.08 & Significant \\
& leadership and work motivation $\rightarrow$ performance \\
\multicolumn{2}{c}{ Source : Data Processing Result } \\
\hline \multicolumn{2}{c}{}
\end{tabular}

Table 3 shows the conclusions of each hypothesis. Hypothesis 1 (H1) states that self efficacy has a positive and significant effect on work motivation of lecturer, SLF value 0.46 and t-value 9.34 (> 1.96) indicates that $\mathrm{H} 1$ can be accepted, so that increased self efficacy of permanent lecturers can increase work motivation of lecturers. This finding is in line with the findings of Baddareen et al. (2015) who found that self efficacy is an important variable to increase motivation, especially in academic matters in Jordan. This finding is also in line with research conducted by Cherian and Jacob (2013) who found the fact that self-efficacy plays an important role in increasing employee motivation. Hypothesis $2(\mathrm{H} 2)$ states that organizational culture has a positive and significant effect on work motivation of lecturers, SLF value 0.16 and t-value 2.88 ( $>1.96)$ indicates that $\mathrm{H} 2$ can be accepted, so that improvements in organizational culture will increase the motivation of the lecturers. This finding is in line with Kamaruddin et al. (2015) who found that organizational culture can improve lecturers' work motivation. Hypothesis 3 (H3) states that leadership has a positive and significant effect on work motivation of lecturers, SLF value 0.26 and t-value $4.46(>1.96)$ indicates that $\mathrm{H} 3$ can be accepted, so that an increase in the quality of leadership will increase the work motivation of lecturers. This finding is in line with the findings of Siddique et al. (2011) who found that leadership is an important variable in improving lecturers' work motivation. Hypothesis 4 (H4) states that self-efficacy, organizational culture and leadership have a positive and significant effect simultaneously on work motivation of lecturers, R2 values 0.43 and f-count 11.26 (> 3.84) indicate that $\mathrm{H} 4$ can be accepted, so that the collectively quality improvement towards self efficacy, organizational culture and leadership will be able to increase the work motivation of lecturers at College of Helath Sciences.

Hypothesis 5 (H5) states that self efficacy has a positive and significant effect on performance of lecturers, SLF value 0.25 and t-value $5.38(>1.96)$ indicate that H5 can be accepted, so that increased self efficacy can improve lecturer performance. This finding is in line with the findings of Motlagh et al. (2011) who found that self efficacy can improve the performance of teaching staff and students. Hypothesis 6 (H6) states that organizational culture has a positive and significant effect on lecturer performance, SLF 0.20 and t-value 4.02 ( $>1.96$ ) indicate that $\mathrm{H} 6$ can be accepted, so that improvements in organizational culture will improve lecturer performance. This finding is in line with the findings of Sangadji and Sopiah (2013) and Marwan et al. (2016) who found that organizational culture has been proven to improve lecturer performance. Hypothesis 7 (H7) states that leadership has a positive and significant effect on lecturer performance, SLF values 0.50 and t-value $8.99(>1.96)$ indicate that $\mathrm{H} 7$ can be accepted, so that improving leadership quality will improve lecturer performance. This finding is in line with the findings of Sudarjat et al. (2015) and Marwan et al. (2016) who found that leadership is a factor that can improve lecturer performance. Hypothesis 8 (H8) states that work motivation has a positive and significant effect on lecturer performance, SLF 0.27 and t-value 5.56 indicate that $\mathrm{H} 8$ can be accepted, so that increased 
motivation will improve lecturer performance. This finding is in line with the findings of Marwan et al. (2016), Victor and Babatunde (2014), Broni (2012) and Asim (2013) who found that work motivation is an important factor that can improve lecturer performance. Hypothesis 9 (H9) states that self-efficacy, organizational culture, leadership and motivation have a positive and significant effect simultaneously on lecturer performance, R2 value 0.79 and fcount 7.08 ( $>3.84)$ indicate that H9 is acceptable, so efforts to increasing self efficacy, improving organizational culture and leadership, also increasing motivation will improve lecturer performance.

\section{Conclusion}

If self efficacy (dimension of magnitude), organizational culture (dimension of innovation and risk taking) and leadership (dimension of academic leadership) can be synergized, it will be able to provide a positive and significant influence on the increasing of work motivation of permanent lecturers of SHS in Jakarta, especially in the dimension of motivator factors. However, considering that self efficacy is the most dominant variable in influencing work motivation, the priority of improvement is more focused on the variable of self efficacy, specifically on the dimension of magnitude. Self efficacy, organizational culture, leadership and work motivation have a positive and significant effect on the performance of SHS permanent lecturers in Jakarta, thus to optimize the improvement of performance is to strengthen and synergize self efficacy, especially the dimension of magnitude, organizational culture, especially the dimension of innovation and risk taking, leadership, especially dimension of academic leadership and work motivation, especially dimension of motivator factor. Considering that leadership is the most dominant variable in influencing performance, the priority of improvement is more focused on variable of leadership, specifically on the dimension of academic leadership. Work motivation is a partial mediating of self efficacy and organizational culture in influencing performance. The influence of self efficacy and organizational culture will be greater in improving performance if it is able to increase work motivation first. While the variable of work motivation does not work optimally in its role as mediating for variable of leadership on performance. Variable of leadership can more directly affect performance compared to work motivation.

\section{Suggestion}

In order to increase work motivation, self efficacy is the most dominant variable in influencing work motivation. Dimension of magnitude is the dimension that most reflect the variable of self efficacy. Indicator of confidence in ability of teaching-research-community service have an average value of less than the total average variable of self efficacy, so it is suggested that the SHS management conducts training or seminars or personal counseling periodically to permanent lecturers in order to increase confidence and ability in the field of teaching-research-communty service. It is also recommended that the SHS management be more selective in holding recruitment systems for permanent lecturers, so that the selection system can truly select and accept permanent lecturers who have good skills, so that good skills will certainly increase the level of self-confidence of lecturers. In order to improve performance, leadership is the most dominant variable in influencing performance. The dimension of academic leader is the dimension that most reflects the leadership variable. Indicator of leader provide facilities to support research activities and leader provide facilities 
to support community service activities have an average value less than total average variable of leadership, so it is recommended that management of SHS reevaluate policies related to the provision of facilities in order to empower permanent lecturers in the field of research and community service, SHS management can also proactively inform and involve permanent lecturers in following a number of grants related to the provision of facilities and infrastructure for research and community service activities held by the government and the private sector.

\section{References}

[1] Asim, Masood. (2013). Impact of motivation on employee performance with effect of training:spesific to education sector of Pakistan. International Journal of Scientific and Research Publications, 3(9), 1-9.

[2] Aslam, A., Ghaffar, A., Talha, T., \& Mushtaq, H. (2015). Impact of compensation and reward system on the performance of an organization: an empirical study on banking sector of Pakistan. European Journal of Business and Social Sciences, 4(8), 319-325.

[3] Baddareen, G. A., Gaith, S., \& Akour, M. (2015). Self efficacy, achievement goals and metacognition as predicators of academic motivation. Procedia Social and Behavioral Sciences.

[4] Bandura, Albert. (2005). Self Efficacy : The exercise of control. New York : Freeman Publisher.

[5] Bass, Bernard M. (2010). Bass \& Stogdill's Handbook of Leadership: Theory, Research, and Managerial Applications. New York: The Free Press.

[6] Broni, A. A. (2012). Relationship between motivation and job performance at the University of Mines and Technology, Tarkwa, Ghana: Leadership Lessons. Scires, 3(3), 309-314.

[7] Cerino, Eric S. (2014). Relationships between academic motivation, self-efficacy, and academic procrastination. Psi Chi Journal of Psychological Research, 19(4), 156-163.

[8] Cherian, J., \& Jacob, J. (2013). Impact of self efficacy on motivation and performance of employees. International Journal of Business and Management, 8(14), 80-88.

[9] Davis, K., \& Newstorm, John W. (2005). Behavior in Organization. Jakarta : Erlangga.

[10] Earls, A. (2004). Building patient loyalty. Computer world, 38.

[11] Salleh, F., Dzulkifli, Z., Abdullah, A., \& Yaakob, H. M. (2011). The effect of motivation on job performance of state government employees in Malaysia. International Journal of Humanities and Social Science, 1(4), 147-154.

[12] Ferris, G.R., Frink, D. D., Galang, M. C., Zhou, J., Kacmar, K. M., \& Howard, J. L. (2005). Perceptions on organizational politics : prediction, stress-related implications, and outcomes. Human Relations, 49, 233-266.

[13] Ghaffari, Sara., Shah, I. M., Burgoyne, J., Nazri, M., \& Salleh, J. R. (2017). The influence of motivation on job performance : a case study at Universiti Teknologi Malaysia. Australian Journal of Basic and Applied Sciences, 11(4), 92-99.

[14] Grund, C., \& Sliwka, Dirk. (2001). The impact of wage increase on job satisfactione empirical evidence and theoritical implications, Bonn: IZA'S Research Area Mobility and Flexibility of Labor Market.

[15] Gunawan, F. E., Heryjanto, A., \& Tannady, H. (2020). Factors affecting job performance of hospital nurses in capital city of Indonesia: Mediating role of 
organizational citizenship behavior. Test Engineering \& Management, 83, 2251322524.

[16] Hair, J.F., Black, W.C., Babin, B.J., \& Anderson, R.E. (2010). Multivariate Data Analysis. New Jersey: Pearson.

[17] Hani S.M.Y, Nur S.M.S, \& Siti R.O.A. (2016). A study of organizational culture and employee motivation in private sector company. Journal of Applied Environmental and Biological Sciences, 6(3S), 50-54.

[18] Hee, O. C., \& Kamaludin, N. H. B. (2016). Motivation and job performance among nurses in the private hospitals in Malaysia. International Journal of Caring Sciences, 9(1), 342-347.

[19] Herzberg, F. (1959). Motivation to Work. New York : John Wiley \& Sons.

[20] Ivancevich, Konopaske, Matteson. (2011). Organizational Behavior and Management. New York: McGraw Hill.

[21] Janssen, O., \& Van Yperen, N.W. (2004). Employees goal orientations, the quality of leader-member exchange, and the outcomes of job performance and job satisfaction. Academy of Management Journal, 47(3), 368-384.

[22] Kamaruddin, T., Mursalim, U. G., Syamsu, N., \& Baharuddin, L. (2015). The impact of antecedent variable on lecturer' performance as mediated by work motivation. International Journal of Humanities and Social Science Invention, 4(10), 54-62.

[23] Kirkpatrick. S. A., \& Locke. E. A. (2001). Leadership: Do traits matter ?. Academy of Management Executive.

[24] Kotter, J. P. (2005). A force for change: How leadership differs from management. New York: Free Press.

[25] McClelland, D. C. (1985). Human Motivation. Glenview, IL: Scot Foresman.

[26] Marwan, Zainuddin, \& Hamid, A. (2016). Effect of organizational culture, leadership behavior, achievement motivation, and job satisfaction on performance of lecturer at private university in the province of Aceh. IOSR Journal of Humanities and Social Science, 21(4), 33-45.

[27] Maslow, A. H. (1943). A theory of human motivation. Psychological Review, 50, 370396.

[28] Mensah, E. B. K., \& Tawiah, K. A. (2016). Employee motivation and work performance : a comparative study of mining companies in Ghana. Journal of Industrial Engineering and Management, 9(2), 255-309.

[29] Mehmet, T. (2013). Organizational variables on nurses' job performance in Turkey: Nursing assessments. Iran Journal of Public Health, 42(3), 261-271.

[30] Motlagh, S. E., Amrai, K., Yazdani, M. J., Abderahim, H. A., \& Souri, H. (2011). The relationship between self-efficacy and academic achievement in high school students. Procedia Social and Behavioral Sciences, 15, 765-768.

[31] Naile, I., \& Selesho, J. M. (2014). The role of leadership in employee motivation. Mediterranean Journal of Social Science, 5(3), 175-182.

[32] Nidhi, M., Dhani, S. C., \& Deepak, G. (2012). Impact of organization culture on employee motivation and job performance. International Journal of Research in Commerce and Management, 3(5), 68-73.

[33] Northouse, P. G. (2007). Leadership theory and practice. London: Thousand Oak.

[34] Omollo, P. A. (2012). Effect of motivation on employee performance of commercial banks in Kenya : A case study of Kenya commercial bank in Migori County. International Journal of Human Resource Studies, 5(2), 87-103. 
[35] Qatmeemalmarhoon, A. A. S., Mohdnoor, K., Abdalla, M. A. D., \& Musbah, A. R. (2017). Effect of motivation on employee's performance and employee's commitment. International Journal of Management and Applied Sciences, 3(9), 39-43.

[36] Rawung, F. H. (2013). The effect of leadership on the work motivation of higher education administration employees (study at Manado State University). IOSR-Journal of Business and Management, 15(1), 28-33.

[37] Rizal, M. Idrus, M. S., Djumahir., \& Mintarti, R. (2014). Effect of compensation on motivation, organizational commitment and employee performance (studies at local revenue management in Kendari City). International Journal of Business and Management Invention, 3(2), 64-79.

[38] Robbins. (2013). Organizational Behavior. New Jersey : Pearson.

[39] Robbins, Stephen., Judge. (2015). Organizational Behavior. New Jersey : Pearson Education.

[40] Robescu, O., \& Iancu, A. G. (2016). The effects of motivation on employees performance in organizations. Valahian Journal of Economic Studies, 7(21), 49-56.

[41] Rosen, C.C., Levy, P. E., \& Hall, R. J. (2006). Placing perceptions of politics in the context of feedback environment, employee attitudes, and job performance. Journal of Applied Psychology, 91(1), 211-230.

[42] Sangadji, E. M., \& Sopiah. (2013). The effect of organizational culture on lecturers' job satisfaction and performance (a research in Muhammadiyah University throughout East Java). International Journal of Learning and Develoment, 3(3), 1-18.

[43] Schermerhorn, John R. (2010). Introduction to Management Asia. John Wiley \& Sons, Inc.

[44] Siddique, Miss Anam., Hassan, D.A., Mannan, K., \& Urooj, Fatima. (2011). Impact of academic leadership on faculty's motivation, and organizational effectiveness in higher education system. International Journal of Business and Social Science, 2(8), 184-191.

[45] Stajkovic, A.D., \& Luthans, F. (1998). Self efficacy and work related performance : a meta analysis. Psychological Bulletin, 124(2), 240-261.

[46] Sudarjat, J., Abdullah, T., \& Sunaryo, W. (2015). Supervision, leadership, and working motivation to teacher's performance. International Journal of Managerial Studies and Research, 3(6), 146-152.

[47] Tannady, H., Andry, J. F., \& Nurprihatin, F. (2020). Determinants factors toward the performance of the employee in the crude palm oil industry in West Sumatera, Indonesia. IOP Conf. Series: Materials Science and Engineering, 771.

[48] Tannady, Hendy., Ismuhadjar., \& Zami, Alex. (2017). Factors affecting the performance of driver: the experience of transjakarta bus driver. International Journal of Research Science \& Management, 4(11), 22-28.

[49] Tannady, H., Tannady, H., Ismuhadjar., \& Zami, A. (2019). The effect of organizational culture and employee engagement on job performance of healthcare industry in province of Jakarta, Indonesia. Quality - Access to Success, 20(169), 18-22.

[50] Tannady, H., Erlyana, Y., \& Nurprihatin, F. (2019). Effects of work environment and self-efficacy toward motivation of workers in creative sector in province of Jakarta, Indonesia. Quality - Access to Success, 20(172), 165-168.

[51] Tannady, H., Gunawan, F. E., \& Heryjanto, A. (2020). Moderation effect of work motivation toward employee engagement of worker in textile industry in province of Central Java, Indonesia. Test Engineering \& Management, 83, 9716-9723.

[52] Victor, A. A., \& Babatunde, E. G. (2014). Motivation and effective performance of academic staff in higher educaion (case study of Adekunle Ajasin University, Ondo 
State, Nigeria). International Journal of Innovation and Research in Educational Sciences, 1(2), 157-163.

[53] Vigoda, E. (2002). Stress related aftermaths to workplace politics: the relationships among politics, job distress, and aggressive behavior in organizations. Journal of Organizational Behavior, 2002, 571-591.

[54] Wagimo \& Ancok, D. (2005). Transformational and transactional leadership relationship with subordinate in military. Journal Psikologi, 32(2), 112-127.

[55] Zameer, H., Ali, S., Nizar, W., \& Amir, M. (2014). The impact of the motivation on the employee's performance in beverage industry of Pakistan. International Journal of Academic Research in Accounting, Finance, and Management Science, 4(1), 293-298.

[56] www.forlap.dikti.go.id 